\title{
Genomic variants reducing expression of two endocytic receptors in 46,XY differences of sex development
}

\author{
Hannah L. Marko ${ }^{1}$ | Nadine C. Hornig ${ }^{2}$ | Regina C. Betz ${ }^{3}$ | \\ Paul-Martin Holterhus $^{2}$ | Janine Altmüller ${ }^{4}$ | Holger Thiele ${ }^{4}$ | Marietta Fabiano ${ }^{5}$ | \\ Hans-Udo Schweikert $^{1}$ | Doreen Braun ${ }^{1}$ | Ulrich Schweizer ${ }^{1}$
}

${ }^{1}$ Institut für Biochemie und Molekularbiologie, Medizinische Fakultät, Rheinische FriedrichWilhelms-Universität Bonn, Bonn, Germany

${ }^{2}$ Klinik für Kinder und Jugendmedizin I, Bereich Pädiatrische Endokrinologie und Diabetologie, Universitätsklinikum SchleswigHolstein, UKSH, Campus Kiel,, Kiel, Germany

${ }^{3}$ Institute of Human Genetics, Medizinische Fakultät, Rheinische Friedrich-WilhelmsUniversität Bonn, Bonn, Germany

${ }^{4}$ Cologne Center for Genomics, University of Cologne, Cologne, Germany

${ }^{5}$ Department of Neurology, Medizinische Fakultät, Rheinische Friedrich-WilhelmsUniversität Bonn, Bonn, Germany

\section{Correspondence}

Ulrich Schweizer, Institut für Biochemie und Molekularbiologie, Universitätsklinikum Bonn, Rheinische Friedrich-Wilhelms-Universität Bonn, Nussallee 11, 53115 Bonn, Germany, Email: uschweiz@uni-bonn.de

\section{Funding information}

Deutsche Forschungsgemeinschaft, Grant/Award Numbers: HO6028/2-1, SCHW168/13-1; Universitätsklinikum Bonn, Grant/Award Number: BONFOR 0-161.0043

\begin{abstract}
Transporter-dependent steroid hormone uptake into target cells was demonstrated in genetically engineered mice and fruit flies. We hypothesized that mutations in such transporters may cause differences in sex development (DSD) in humans. Exome sequencing was performed in 16 genetically unsolved cases of 46,XY DSD selected from an anonymized collection of 708 lines of genital fibroblasts (GF) that were taken from individuals with incomplete virilization. Selection criteria were based on available biochemical characterization of GF compatible with reduced androgen uptake. Two unrelated individuals were identified with mutations in LDL receptor-related protein 2 (LRP2), a gene previously associated with partial sex steroid insensitivity in mice. Like $\mathrm{Lrp}^{-/-}$mice, affected individuals had nondescended testes. Western blots on GF confirmed reduced LRP2 expression, and endocytosis of sex hormone-binding globulin was reduced. In three unrelated individuals, two with undescended testes, mutations in another endocytic receptor gene, limb development membrane protein 1 like (LMBR1L), were detected. Two of these individuals had mutations affecting the same codon. In a transfected cell model, mutated LMBR1L showed reduced cell surface expression. Our findings suggest that endocytic androgen uptake in complex with sex hormone-binding globulin is relevant in human. LMBR1L may play a similar role in androgen uptake.
\end{abstract}

\section{KEYWORDS}

androgen, DSD, exome sequencing, LIMR, Lipocalin receptor, Lipocalin-1-interacting membrane receptor, Megalin

\section{1 | INTRODUCTION}

Differentiation of the male phenotype depends on the action of androgens (Audi et al., 2018). Inborn errors of androgen metabolism or action accordingly lead to failure of male phenotype differentiation. Androgen action is mediated by the androgen receptor (AR), a nuclear receptor located in the cytoplasm of specific hormone target cells (Brinkmann et al., 1991). It is often neglected that hormonal ligands of nuclear receptors need to cross the plasma membrane to reach their intracellular receptor, because there is a 
widespread notion that these ligands passively diffuse through the lipid bilayer. Over decades this simplified view has been repeatedly challenged. In the case of thyroid hormones (TH), it is now firmly established, that mutations in the plasma membrane transport protein monocarboxylate transporter 8 (MCT8/SLC16A2) cause a syndrome of atypical TH resistance, because several cell types are dependent on MCT8-mediated TH uptake (Dumitrescu et al., 2004; Friesema et al., 2004; Schwartz et al., 2005). Recently it has been demonstrated that the molting hormone, the steroid ecdysone, in the fruit fly Drosophila melanogaster is actively stored in exocytotic vesicles (Yamanaka et al., 2015), and upon release it is taken up by target cells via the ecdysone importer Ecl, systematically classified as plasma membrane transporter Oatp74D (Okamoto et al., 2018). Inactivating mutations in $\mathrm{ECl}$ lead to specific ecdysone-dependent developmental defects in target cells (Okamoto \& Yamanaka, 2020). However, an essential steroid carrier in humans is not yet known despite repeated attempts to characterize steroid transporters at the plasma membrane in mammals (Lackner et al., 1998; G. S. Rao, 1981; M. L. Rao et al., 1976). It has been shown that hydrophobic hormones (e.g. TH, sex steroids, cortisol, and vitamin D), but also retinol, are circulating in complex with plasma transfer proteins, and that specific endocytic receptors can mediate their cellular uptake as transfer protein/ligand complexes (Kawaguchi et al., 2007; Willnow \& Nykjaer, 2010). For sex steroids, this concept has been clearly established in a genetic mouse model of LDL receptor-related protein 2 (Lrp2) deficiency. LRP2 acts as an endocytic receptor for sex hormone-binding globulin (SHBG). $\mathrm{Lrp2}^{-/-}$mice showed defects in specific sex hormone-dependent developmental processes, including testicular descent and vaginal opening (Hammes et al., 2005).

We, therefore, set out to search for mutations in plasma membrane proteins that are involved in steroid uptake into cells. We reasoned that 46,XY DSD individuals with mutations in such genes could be identified by exome sequencing of DNA derived from cultured genital fibroblasts (GF). In particular, GF with a welldocumented biochemical evidence of reduced androgen (DHT) uptake were selected. To exclude mutations affecting primarily intracellular androgen-dependent gene expression, we focused on cells that had a normal APOD (apolipoprotein D) induction upon stimulation with $10 \mathrm{nM}$ DHT in vitro (Hornig et al., 2016). Cells with abnormally low 5a-reductase 2 activity were excluded. We further surmised that one reason why mutations in putative steroid hormone uptake transporter genes have not yet been discovered in DSD is that such transporters might partially compensate for the lack of others because of overlapping substrate specificities or expression patterns, thus we focused on individuals with incomplete virilization excluding complete androgen insensitivity syndrome. Altogether, we subjected 16 GF cell lines to exome sequencing. In five cell lines we found mutations in two endocytic receptor genes, LRP2 and limb development membrane protein 1 like (LMBR1L), which both have not been associated with DSD in human. As mentioned above, LRP2 is known to mediate testosterone-dependent testicular descend in mice and our report for the first time suggests a similar role in human. LMBR1L encodes a lipocalin receptor. Lipocalins are proteins that bind hydrophobic ligands, like steroids, in body fluids. Which lipocalin fails to be bound by mutant LMBR1L in incomplete virilization and which ligand is involved remains to be established.

\section{2 | MATERIALS AND METHODS}

\subsection{Study design}

The study was performed with consent of the Ethics Committee of the Medical Faculty of the Christian-Albrechts-Universität (AZ: D415/11). The GF cell line collection, 5a-reductase 2 assay, DHT binding and stability assays were described before (Weidemann et al., 1996). Since we aimed to identify potential steroid hormone transporter genes, we followed the following inclusion and exclusion criteria (Table 1).

Inclusion criteria: clinical diagnosis of Differences of Sex Development (DSD), confirmed 46,XY karyotype, biochemical evidence for reduced DHT binding or reduced DHT binding stability in whole-cell assays.

Exclusion criteria: clinical genetic diagnosis including known mutations in the $A R$ gene, abnormal $5 a$-reductase 2 activity, $A P O D$ induction below the cut-off of 2.29/2.36-fold, depending on biopsy localization (Hornig et al., 2016).

\section{2 | APOD assay}

$A P O D$ is the only gene in cultured GF that remains reliably responsive to androgen stimulation and thus the APOD assay is a good probe for the transcriptional response to androgens (Hornig et al., 2016). The level of APOD messenger RNA (mRNA) is determined via quantitative reverse-transcription polymerase chain reaction (qRT-PCR) assay after over-night incubation with $10 \mathrm{nM}$ DHT (Hornig et al., 2016). The fold-induction of $A P O D$ in DHT-stimulated cells compared to control cells is interpreted with respect to the position of the biopsy. The stimulation with $10 \mathrm{nM}$ DHT, a high supra-physiological concentration, has been selected for its sensitivity to identify functionally impaired $A R$ mutations. We assumed that a moderate delay in DHT uptake may not be evident in the current APOD assay as optimized to detect $A R$ mutations. The high DHT concentration and overnight incubation may compensate partially for reduced uptake velocity.

\section{3 | Exome sequencing}

Exome sequencing was performed at the Cologne Center of Genomics (CCG) using an Agilent sureselect v6_r2 enrichment kit. The CCG program varbank (https://varbank.ccg.uni-koeln.de) was used for data analysis. The exome data were compared to $\mathrm{Hg} 19$ and analyzed for single nucleotide variants possibly causing DSD. Per exome, only variants with an allele frequency $\leq 0.1 \%$ and their absence from the varbank inhouse database were considered for 


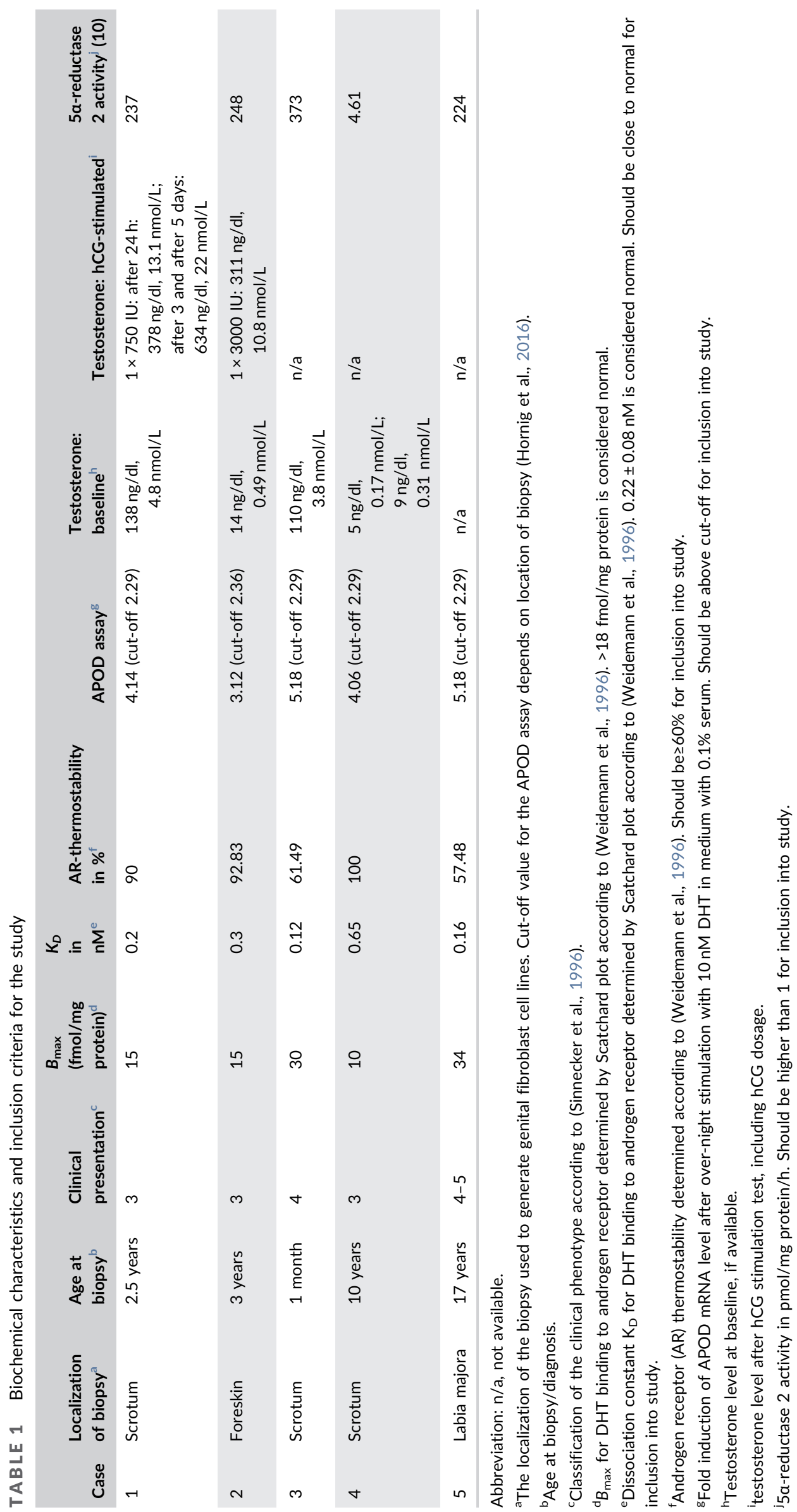


further analysis. Resulting variants were compared to the following list of 100 genes that have been previously associated with DSD: AKAP2, AKR1C1, AKR1C2, AKR1C4, AMH, AMHR2, ANOS1, AR, ARX, ATF3, ATRX, BMP4, BMP7, BNC2, CBX2, CHD7, CUL4B, CYB5A, CYP11A1, CYP17A1, CYP19A1, DAX1, DHCR7, DHH, DHX37, DMRT1, DMRT2, DUSP6, EMX2, ESR2, FGF17, FGF8, FGFR1, FGFR2, FLRT3, FSHR, GATA4, GHR, GLI2, GNRH1, GNRHR, HESX1, HHAT, HOXA13, HOXA4, HOXB6, HS6ST1, HSD17B3, HSD3B2, IL17RD, INSL3, KAL1, KISS1, KISS1R, LEP, LHB, LHCGR, LHFPL5, LHX3, LHX9, MAMLD1, MAP3K1, MID1, MYRF, NELF, NLGN4X, NMT2, NROB1, NR5A1, POLR3A, POR, POU1F1, PROK2, PROKR2, PROP1, PSMC3IP, RSPO1, RXFP2, SEMA3A, SOX10, SOX2, SOX3, SOX8, SOX9, SPRY4, SRD5A2, SRY, STAR, STARD8, TAC3, TACR3, TDRD7, TSPYL1, TUBB3, WDR11, WNT4, WT1, WWOX, ZFPM2, ZNRF3. The list was compiled based on the following references (Audi et al., 2018; Baetens et al., 2019; Buonocore et al., 2019; Eggers et al., 2016; Fan et al., 2017; Hughes et al., 2019; Xu et al., 2019). Variants with gnomAD scores $>10^{*-3}$ were considered frequent and likely not pathogenic. To assess potential pathogenicity, several web-based prediction tools have been assessed (see web-based resources).

\section{4 | Sanger sequencing}

Single nucleotide variants from exome data were confirmed by Sanger sequencing using the primers given in Table S1.

\section{5 | Cell culture}

Cell lines were cultured in a humified atmosphere at $37^{\circ} \mathrm{C}$ and $5 \% \mathrm{CO}_{2}$. Genital skin fibroblasts were cultured in MEM with $10 \%$ fetal bovine serum (FBS), 1\% penicillin/streptomycin (Pen/Strep) (5000 U/ml), 1\% GlutaMAX (100×), 1\% sodium pyruvate $(100 \mathrm{mM})$, 1\% MEM vitamin solution (100x) (each Thermo Fisher Scientific) and $0.2 \%$ uridine (Sigma-Aldrich). Human embryonic kidney (HEK293) cells were grown in DMEM/F-12 (1:1) (Thermo Fisher Scientific) with 10\% FBS and 1\% Pen/Strep. HAP1 cells (Horizon, HZGHC55716) were cultured in IMDM (Thermo Fisher Scientific) with 10\% FBS and $1 \%$ Pen/Strep.

\subsection{Western blot}

Genital skin fibroblasts were cultured on $10 \mathrm{~cm}$ dishes and harvested for isolation of protein for which homogenization buffer $(250 \mathrm{mM}$ Sucrose, $20 \mathrm{mM}$ HEPES [2-(4-(2-Hydroxyethyl)piperazin-1-yl) ethanesulfonic acid], $1 \mathrm{mM}$ EDTA, $1 \mathrm{mM}$ DTT, pH 7.4 in $\mathrm{dH}_{2} \mathrm{O}$ ) together with $1 \mathrm{mM}$ DTT and $1 \times$ protease-inhibitor (cOmplete Tablets EASYpack Protease Inhibitor Cocktail Tablets; Roche) was used. Forty micrograms of protein was separated on $10 \%$ SDS gels and transferred onto nitrocellulose membranes. Protein transfer was confirmed by Ponceau staining. The nitrocellulose membranes were incubated with primary antibodies (LRP2 RRID: AB_10673466, 1:1000; $\beta$-Actin RRID: AB_262011, 1:25.000; Vinculin RRID: AB_477629, 1:1000; HA-tag RRID: AB_307019, 1:1000) over night at $4^{\circ} \mathrm{C}$ and afterwards for $1 \mathrm{~h}$ at room temperature with HRP-conjugated secondary antibody (HRP-conjugated anti-mouse, RRID: $\quad A B \_10015289 ; \quad H R P$-conjugated anti-rabbit, RRID: $A B \_2313567$, each 1:15,000). Signals were detected using ECLsolution (Thermo Fisher Scientific). Antibodies against $\beta$-actin or vinculin were used as loading controls.

\section{7 | Surface biotinylation}

Surface biotinylation was used for purification and detection of cell surface proteins. Biotinylation was performed according to the protocol of the Pierce Cell Surface Protein Isolation Kit (Thermo Fisher Scientific) with minor changes: cells were centrifuged at $1000 \mathrm{~g}$ at $4^{\circ} \mathrm{C}$ for $5 \mathrm{~min}$ for washing, and cells were lysed with $125 \mu$ lysis buffer with protease inhibitor (cOmplete Tablets EASYpack Protease Inhibitor Cocktail Tablets, Roche, Switzerland). Proteins were eluted from the affinity matrix with $250 \mu \mathrm{l}$ of a modified elution buffer (50 mM Tris pH 7.5, 10\% glycerin, 50 mM DTT). Biotinylated proteins $(75 \mu \mathrm{l})$ were separated on $10 \%$ SDS gels and tested for (HA-tagged-) LMBR1L expression by western blot analysis (HA-tag antibody RRID: $\left.A B \_307019\right)$. An antibody against $\beta$-actin (RRID: AB_262011) was used for loading control.

\section{8 | Endocytosis assay}

Thirty-five thousand cells of genital skin fibroblasts were seeded on glass coverslips (diameter: $13 \mathrm{~mm}$ ) in DMEM without phenol red (Thermo Fisher Scientific) $+1 \%$ Pen $/$ Strep $+5 \%$ FBS. Human recombinant Sex hormone-binding globulin (SHBG; R\&D Systems) was labeled with $\mathrm{pHrodo}^{\mathrm{TM}} \mathrm{iFL}$ Red Microscale Protein Labeling Kit (Thermo Fisher Scientific) according to the manufacturer's protocol. The day after seeding the cells were incubated with DMEM without phenol red $+1 \%$ Pen/Strep and $5 \% \mathrm{FBS}$ for $24 \mathrm{~h}$ at $37^{\circ} \mathrm{C}$ and $5 \% \mathrm{CO}_{2}$. The cells were then serum-starved overnight and incubated with ECGreen-Endocytosis Detection fluorescent dye (Dojindo, Europe) diluted 1:4000 in medium. ECGreen-labeled fibroblasts were incubated with pHrodo-labeled SHBG for 10 min. Afterwards cells were washed once with phosphate-buffered saline and fixed in $4 \%$ paraformaldehyde for $5 \mathrm{~min}$. After additional three washing steps, the cells were stained with DAPI, washed again and mounted on a slide with Immu-Mount (Thermo Fisher Scientific).

\subsection{Image acquisition and analysis}

Images were acquired using an AxioVert 200 fluorescence microscope and ZEN microscopy software (Zeiss) and VisiScope CSU-W1 spinning disk confocal microscope and VisiView Software 
(Visitron Systems $\mathrm{GmbH}$ ). Lasers and exposure time settings were maintained constant for all cell lines and images were obtained using a $\times 63$ objective with z-step size on $0.25 \mu \mathrm{m}$. Six images per cell line were randomly taken and used for quantification with the "analyze particles" function in the free software Fiji (ImageJ). The number of particles (with red and green colocalized) per image was divided manually by the number of cells with complete nucleus in the image field. Images in Figure 3a were acquired with the confocal microscope. Quantification was performed on images taken with both microscopes.

\subsection{0 | qRT-PCR}

Total RNA was isolated from cultured cells (GFs, HAP1 cells) using TRIzol according to its protocol (Thermo Fisher Scientific). Complementary DNA (cDNA) was synthesized from $1 \mu \mathrm{g}$ RNA using the iScript $^{\mathrm{TM}}$ cDNA Synthesis Kit (Bio-Rad) according to the manufacturer's protocol. Quantitative PCR (qPCR) was performed using Takyon Low ROW SYBR 2× Mastermix blue dTTP (Eurogentec) with the primers: LMBR1L_RT Fw 5'-T TTAGACATGGAGCTGCTAC ACAG-3', Rv 5'-GAGACCTGGCCTAAGGAGGTA-3'; 18S rRNA Fw 5'-TTGACGGAAGGGCACCACCAG-3', Rv 5'-GCACCACCACCCAC GGAATCG-3'.

\subsection{1 | Cloning of LMBR1L}

Human LMBR1L was amplified from cDNA obtained from wildtype HAP1 cells (Horizon/PerkinElmer, cat \# C631) with the following primers: LMBR1L-5'-UTR Fw 5'-GAGTTTCTGTCGCAGGCTGCGA GGAAAG-3', LMBR1L-3'-UTR Rv 5'-CAGATTCCAGGTCCTGA GGTCCAAGTAGCCTTG- $3^{\prime}$ and subcloned into pGEMT-easy. HAtag sequence was added at the $\mathrm{C}$-terminal and $\mathrm{N}$-terminal end, respectively, with the following primers: LMBR1L-HA-Tag-N-terminal Fw 5'-AGATCTAAGCTTGCCACCATGTACCCTTATGATGTCCCAGA CTATGCAATGGAAGCACC TGACTACGAAGTGCTATCCGTG-3', LMBR1L-HA-Tag-N-terminal Rv 5'-AGATCTTCTAG ATCACTGGTG CTGGGTCTTCCTAGATGCCTG-3'; LMBR1L-HA-Tag-C-terminal Fw 5'-AG ATCTAAGCTTGCCACCATGGAAGCACCTGACTACGAAGTG CTATCCGTG-3'; LMBR1L-HA-Tag-C-terminal Rv 5'-TCTAGAAGA TCTTCATGCATAGTCTGGGACATCATAAGGGTAC TGGTGCTGGGT CTTCCTAGATGCCTG-3'. Tagged LMBR1L was cloned into the expression vector pcDNA3. Expression of full-length LMBR1L was verified by transient transfection into cultured HEK293 cells followed by western blot analysis (Figure S1).

\subsection{2 | Mutagenesis of LMBR1L}

Mutations for creating the $L M B R 1 L$ mutants found in individuals 3,4 , and 5 were introduced in the C-terminal HA-tagged LMBR1L using the QuikChange Lightning Site-Directed Mutagenesis kit (Agilent
Technologies) with the following primers: p.Arg288Gln: Fw 5'-G CTGGAGAAGAGGCAGAAGGCTTCAGCCT-3', Rv 5'-AGGCTGAAG CC TTCTGCCTCTTCTCCAGC-3'; p.Arg288Trp: Fw 5'-TGCTGGAGA AGAGGTGGAAGGCTT CAGCC-3', Rv 5'-GGCTGAAGCCTTCCACCT CTTCTCCAGCA-3', p.lle39Val: Fw 5'-ACATCCTCTGCCACGTCTT CCTGACCCGC-3', Rv 5'-GCGGGTCAGGAAGACGTGGCA GAGGA TGT-3'.

\subsection{3 | Transfection}

HEK293 and HAP1-LMBR1L knockout cells (Horizon, PerkinElmer; catalog number HZGHC007405c011, containing a $7 \mathrm{bp}$ in-frame deletion), respectively, were transiently transfected with C-terminal HA-tagged LMBR1L (wildtype and mutants) as well as pcDNA3. For transfection cells were plated 1:1 (HEK293 cells) and 1:3 (HAP1-LMBR1L knockout cells) on $6 \mathrm{~cm}$ cell culture dishes with $5 \mathrm{ml}$ of the respective cell culture medium. PANfect transfection buffer (PAN-Biotech) was added to $3 \mu \mathrm{g}$ plasmid DNA to a total volume of $125 \mu \mathrm{l}$. Then, a mixture of $110 \mu \mathrm{l}$ transfection buffer and $15 \mu \mathrm{l}$ transfection reagent (PAN-Biotech) was added. After $20 \mathrm{~min}$ incubation, the transfection mixture was added dropwise onto the cells. Forty-eight hours after transient transfection the cells were harvested for further analysis.

\subsection{Image quantification and statistics}

ImageJ was used for western blot quantification. GraphPad Prism 6 was used for statistical tests and graphics.

\section{3 | RESULTS}

Among 16 GF cell lines subjected to exome sequencing, five showed heterozygous mutations in two genes encoding endocytic receptors that are known to internalize plasma transfer proteins, LRP2 (NM_004525.2) and LMBR1L (NM_018113.3) (Figure 1).

Individuals 1 and 2 carry heterozygous mutations in LRP2, but no other mutation in any of the list of 100 genes so far associated with DSD (see methods). Phenotypically, both individuals show hypospadias, bifid scrotum, and micropenis (Table 2). Intriguingly, both individuals display inguinal testes, a finding that is reminiscent of the characteristic lack of testicular descend in Lrp2-deficient mice (Hammes et al., 2005). Individual 1 carries the rare LRP2 mutation c.5120C > T (p.Ser1707Phe, SCV0019345574). This individual harbors two additional variants in LRP2 (SCV0019345575 and SCV001934576), which are relatively frequent and most likely not pathogenic (Table 3). Individual 1 also shows an absence of the septum pellucidum that is reminiscent of midline defects observed in $\mathrm{Lrp2}^{-/-}$mice (Hammes et al., 2005). Individual 2 carries only the variant c.11288A $>T$ (p.Glu3763Val, SCV0019345577) in LRP2. Whether individual 2 lacks the septum pellucidum has not been 


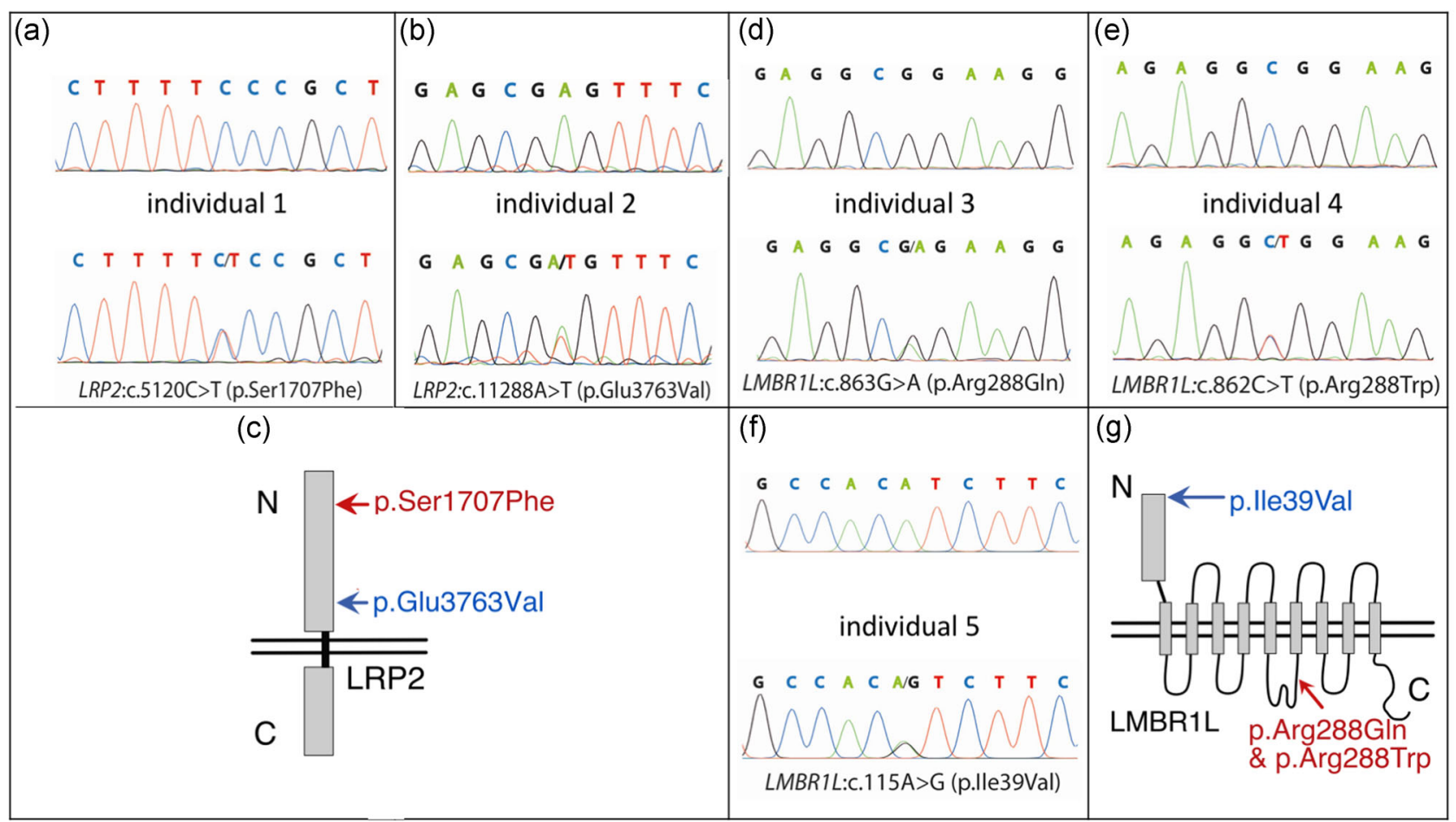

FIGURE 1 Sanger sequencing of genomic DNA in individuals 1-5. (a) Individual 1 carrying the heterozygous variants c.5120C $>$ T (p.Ser1707Phe, SCV0019345574), c.6256A>T (p.Thr2086Ser, SCV0019345575) and c.10165A>G (p.lle3389Val, SCV0019345576) in LRP2 (NM_004525.2). (b) Individual 2 carrying the heterozygous variant c.11288A >T (p.Glu3763Val, SCV0019345577) in LRP2. (c) Schematic of LRP2 localizing the mutated amino acids found in individuals 1 and 2. (d) Individual 3 carrying the heterozygous variant c.863G>A (p.Arg288Gln, SCV0019345578) in LMBR1L (NM_018113.3). (e) Individual 4 carrying the heterozygous variant c.862C>T (p.Arg288Trp, SCV0019345579) in LMBR1L. (f) Individual 5 carrying the heterozygous variant c.115A>G (p.lle39Val, SCV0019345580) in LMBR1L. (g) Schematic of LMBR1L for localizing the mutated amino acids found in individuals 3,4 , and 5

investigated. Predictions of pathogenicity differed for p.Ser1707Phe between benign and damaging (Table 3). Because of the replacement of a small amino acid with a large, aromatic one, we decided that experimental examination of the mutation was required.

To find out whether the novel variants in the LRP2 gene affect LRP2 protein expression, we quantified LRP2 by western blot analysis in GF derived from these individuals. We performed three independent experiments of cell culture and western blot analysis comparing the two patient GF with a set of five control GF from individuals not diagnosed with DSD. Consistent with a potential causative role of the LRP2 mutations, LRP2 protein levels were significantly reduced by at least $50 \%$ compared to the average of control cells (Figure 2). In accordance with a disease mechanism independent of testicular development or androgen biosynthesis, baseline testosterone and hGC-stimulated testosterone values did not show abnormalities in individuals 1 and 2 (Table 1).

We wanted to find out whether reduced LRP2 expression impairs its function as an endocytic receptor for SHBG. To this end, recombinant SHBG was conjugated with the $\mathrm{pH}$-sensitive rhodamine dye, $\mathrm{pHrodo}$ red. The fluorescence of pHrodo red increases massively when the $\mathrm{pH}$ is lowered to 4.5 as in lysosomes. After over-night serum starvation, GFs derived from individuals 1 and 2 were exposed to conjugated SHBG for $10 \mathrm{~min}$ and fixed. The cells were also pre-incubated with a $\mathrm{pH}$-sensitive cell-impermeant dye, ECGgreen, which is taken up by endocytosis and increases its green fluorescence upon acidification in lysosomes. When we quantified the number of pHrodo-labelled lysosomes per cell in the GFs, we found a significant reduction of about $50 \%$ in GFs from individuals 1 and 2 compared to the mean of a set of three control GF cell lines (Figure 3). We conclude that the decreased LRP2 expression in GF containing LRP2 variants leads to decreased endocytosis of SHBG and thus may impair uptake of male sex hormones in cells which depend on this process.

Individuals 3 and 4 show PAIS (partial androgen insensitivity)-like phenotypes with micropenis, hypospadias, bifid scrotum, and inguinal testes (Table 2). Both carry mutations in the limb development membrane protein 1 like gene (LMBR1L), but not in any gene previously associated with DSD (Figure 1). LMBR1L was initially cloned as lipocalin-1 interacting membrane receptor gene, LIMR (Wojnar et al., 2001). Lipocalins are a family of proteins binding hydrophobic ligands, including APOD and retinol-binding protein (RBP). Individual 3 carries c.863G >A (p.Arg288Gln, SCV0019345578) and individual 4 c.862C $>T$ (p.Arg288Trp, SCV0019345579). It is intriguing that the two mutations identified in individuals 3 and 4 affect the same amino acid at position 288. For this reason, we continued to consider the p.Arg288GIn mutation as potentially detrimental, although the mutation is considered benign by all webbased prediction programs. In the third individual with a missense mutation in LMBR1L c.115A>G (p.lle39Val, SCV0019345580), individual 5, exome sequencing detected additional mutations in four well-established 
TABLE 2 Mutation, genome coordinate, and clinical description

\begin{tabular}{|c|c|c|c|}
\hline Case & Mutation & Hg19 genome coordinate & Clinical description \\
\hline 1 & $\begin{array}{l}\text { Missense mutation in the LRP2 gene } \\
\text { NM_004525.2:c.5120C>T (p.Ser1707Phe) } \\
\text { SCV001934574 } \\
\text { Missense mutation in the LRP2 gene } \\
\text { NM_004525.2:c.6256A>T (p.Thr2086Ser)* } \\
\text { SCV0019345575 } \\
\text { Missense mutation in the LRP2 gene } \\
\text { NM_004525.2:c.10165A }>\mathrm{G} \text { (p.lle3389Val)* } \\
\text { SCV001934576 }\end{array}$ & $\begin{array}{l}\text { Hg19 } \\
\text { 2: } 170088331 \\
\text { Hg19 } \\
\text { 2: } 170068502\end{array}$ & $\begin{array}{l}\text { PAIS-like, hypoplastic bifid scrotum, micropenis, } \\
\text { hypospadias, inguinal testes, agenesis septum } \\
\text { pellucidum }\end{array}$ \\
\hline 2 & $\begin{array}{l}\text { Missense mutation in the LRP2 gene } \\
\text { NM_004525.2:c.11288A>T (p.Glu3763Val) } \\
\text { SCV001934577 }\end{array}$ & $\begin{array}{l}\text { Hg19 } \\
\text { 2: } 170027153\end{array}$ & $\begin{array}{l}\text { PAIS-like, hypoplastic bifid scrotum, micropenis, } \\
\text { hypospadias, inguinal testes }\end{array}$ \\
\hline 3 & $\begin{array}{l}\text { Missense mutation in the LMBR1L gene } \\
\text { NM_018113.3:c.863G>A (p.Arg288GIn) } \\
\text { SCV001934578 }\end{array}$ & $\begin{array}{l}\text { Hg19 } \\
12: 49495970\end{array}$ & $\begin{array}{l}\text { PAIS-like, bifid scrotum, micropenis, hypospadias, } \\
\text { one inguinal testis, one missing testis }\end{array}$ \\
\hline 4 & $\begin{array}{l}\text { Missense mutation in the LMBR1L gene } \\
\text { NM_018113.3:c.862C>T (p.Arg288Trp) } \\
\text { SCV001934579 }\end{array}$ & $\begin{array}{l}\text { Hg19 } \\
\text { 12: } 49495971\end{array}$ & $\begin{array}{l}\text { PAIS-like, hypoplastic scrotum, micropenis, } \\
\text { hypospadias, inguinal testes }\end{array}$ \\
\hline 5 & $\begin{array}{l}\text { Missense mutation in the LMBR1L gene } \\
\text { NM_018113.3:c.115A>G (p.lle39Val) } \\
\text { SCV001934579 } \\
\text { Missense mutation in the HSD17B3 gene } \\
\text { NM_000197.1:c.3G>A (p.0?) } \\
\text { Missense mutation in the ZFPM2 gene } \\
\text { NM_012082.3:c.959A>G (p.His320Arg) }\end{array}$ & $\begin{array}{l}\text { Hg19 } \\
\text { 12: } 49500786 \\
\text { Hg19 } \\
\text { 9: } 99064384 \\
\text { Hg19 } \\
\text { 8: } 106811171\end{array}$ & $\begin{array}{l}\text { PAIS-like, labia majora, clitoromegaly/micropenis, } \\
\text { hypospadias, rudimentary vagina }\end{array}$ \\
\hline
\end{tabular}

DSD genes. A homozygous c.3G>A (p.0?) mutation in HSD17B3 (NM_000197.2), a heterozygous c.205T>C (p.Trp69Arg) variant in INSL3 (NM_001265587.2), the hemizygous c.16C>A (p.His6Asn, rs191365011) variant in NROB1 (NM_000475.5), and a heterozygous c.959A>G (p.His320Arg) variant in ZFPM2 (NM_012082.3). Therefore, we cannot firmly conclude from our data that the c.115A>G (p.lle39Val) mutation in LMBR1L is pathogenic in patient 5 .

Since we did not know whether and how the mutations in LMBR1L might affect gene expression, we performed qRT-PCR on total RNA from GF. While mRNA expression of LMBR1L was significantly reduced in the fibroblasts with the p.Arg288GIn mutation, we found an upregulation in cells with the p.Arg288Trp mutation (Figure 4). Data on the p.lle39Val mutation were inconclusive because of large variation of the results. Both mRNA upregulation or downregulation could be physiological responses to mutated LMBR1L caused by possible mRNA instability, for which the increase in p.Arg288Trp mRNA production might be an attempted compensation mechanism. The next question was whether the missense mutations may affect expression of the LMBR1L protein in GF. Attempts to assess LMBR1L protein expression in GF were unsuccessful with two different commercial antibodies. We, therefore, cloned the human
LMBR1L, and expressed the protein with $\mathrm{N}$ - or C-terminal HA-tag in HEK293 cells with similar results (Figure S1). Electrophoretic mobility of $40 \mathrm{kDa}$ seen for our cloned protein corresponds with recombinantly expressed protein (Hesselink \& Findlay, 2013). We then introduced the three DSD case-derived mutations into the cDNA of C-terminal HA-tagged LMBR1L and transiently transfected HAP1 cells made deficient for endogenous LMBR1L (Figure S1 and S2). LMBR1L protein expression and exposure at the cell surface were assessed by Western blot and surface biotinylation, respectively. While LMBR1L protein abundance in whole cell lysate was not affected by the mutations, expression of all three mutant LMBR1L proteins was significantly reduced at the cell surface (Figure 5).

\section{4 | DISCUSSION}

Here we describe the outcome of an exome sequencing strategy in GF cell lines taken from cases of 46,XY DSD individuals with incomplete virilization. The primary goal of our study was to identify mutations in genes involved in cellular steroid uptake and the cases were selected according to biochemical measurements with the idea 
TABLE 3 Mutation pathogenicity analysis using web-based resources

\begin{tabular}{|c|c|c|c|c|}
\hline & PolyPhen-2 & fathmm & MutationTaster2 & $\begin{array}{l}\text { gnomAD allele } \\
\text { frequency }\end{array}$ \\
\hline $\begin{array}{l}\text { Individual } 1 \\
\text { LRP2 } \\
\text { p.Ser1707Phe } \\
\text { SCV001934574 }\end{array}$ & $\begin{array}{l}\text { Benign } \\
0.108 \\
\text { Sensitivity } 0.93 \\
\text { Specificity } 0.86\end{array}$ & $\begin{array}{l}\text { Damaging } \\
-3.81\end{array}$ & Poly-morphism & $7.97 e-5$ \\
\hline $\begin{array}{l}\text { Individual } 1 \\
\text { LRP2 }^{\text {a }} \\
\text { p.Thr2086Ser SCV0019345575 }\end{array}$ & $\begin{array}{l}\text { Benign } \\
0.001 \\
\text { Sensitivity } 0.99 \\
\text { Specificity } 0.15\end{array}$ & $\begin{array}{l}\text { Damaging } \\
-2.73\end{array}$ & Poly-morphism & $1.37 e-3$ \\
\hline $\begin{array}{l}\text { Individual } 1 \\
\text { LRP2 }^{\text {a }} \\
\text { p.lle3389Val SCV001934576 }\end{array}$ & $\begin{array}{l}\text { Probably } \\
\text { damaging } \\
0.998 \\
\text { Sensitivity } 0.27 \\
\text { Specificity } 0.99\end{array}$ & $\begin{array}{l}\text { Damaging } \\
-3.08\end{array}$ & Disease-causing & $1.85 e-3$ \\
\hline $\begin{array}{l}\text { Individual } 2 \\
\text { LRP2 } \\
\text { p.Glu3763Val SCV001934577 }\end{array}$ & $\begin{array}{l}\text { Probably damaging } \\
1.000 \\
\text { Sensitivity } 0.00 \\
\text { Specificity } 1.00\end{array}$ & $\begin{array}{l}\text { Damaging } \\
-3.95\end{array}$ & Disease-causing & $2.40 e^{-4}$ \\
\hline $\begin{array}{l}\text { Individual } 3 \\
\text { LMBR1L p.Arg288GIn SCV001934578 }\end{array}$ & $\begin{array}{l}\text { Benign } \\
0.000 \\
\text { Sensitivity } 1.00 \\
\text { Specificity } 0.00\end{array}$ & $\begin{array}{l}\text { Tolerated } \\
1.44\end{array}$ & Poly-morphism & $1.10 e-4$ \\
\hline $\begin{array}{l}\text { Individual } 4 \\
\text { LMBR1L p.Arg288Trp SCV001934579 }\end{array}$ & $\begin{array}{l}\text { Probably } \\
\text { damaging } \\
0.964 \\
\text { Sensitivity } 0.78 \\
\text { Specificity } 0.95\end{array}$ & $\begin{array}{l}\text { Tolerated } \\
1.55\end{array}$ & Poly-morphism & $1.06 e-5$ \\
\hline $\begin{array}{l}\text { Individual } 5 \\
\text { LMBR1L } \\
\text { p.Ile39Val SCV001934579 }\end{array}$ & $\begin{array}{l}\text { Benign } \\
0.000 \\
\text { Sensitivity } 1.00 \\
\text { Specificity } 0.00\end{array}$ & $\begin{array}{l}\text { Tolerated } \\
1.47\end{array}$ & Disease-causing & $2.40 e-5$ \\
\hline $\begin{array}{l}\text { Individual } 5 \\
\text { heterozygous } \\
\text { ZFPM2 } \\
\text { p.His320Arg }\end{array}$ & $\begin{array}{l}\text { Probably } \\
\text { damaging } \\
0.959\end{array}$ & $\begin{array}{l}\text { Tolerated } \\
-1.20\end{array}$ & Disease-causing & $1.61 e-5$ \\
\hline $\begin{array}{l}\text { Individual } 5 \\
\text { homozygous } \\
\text { HSD17B3 } \\
\text { c.3G>A } \\
\text { p.0? }\end{array}$ & $\begin{array}{l}\text { Benign } \\
0.063 \\
\text { Sensitivity } 0.94 \\
\text { Specificity } 0.84\end{array}$ & $\begin{array}{l}\text { Damaging } \\
-1.86\end{array}$ & Disease-causing & $7.96 e-6$ \\
\hline $\begin{array}{l}\text { Individual } 5 \\
\text { heterozygous } \\
\text { INSL3 } \\
\text { c. } 205 \text { T >C p.Trp69Arg } \\
\text { rs201125714 }\end{array}$ & $\begin{array}{l}\text { Probably damaging } \\
1.000 \\
\text { Sensitivity } 1.00 \\
\text { Specificity } 0.00\end{array}$ & $\begin{array}{l}\text { Damaging } \\
-2.27\end{array}$ & Poly-morphism & $1.82 e-4$ \\
\hline $\begin{array}{l}\text { Individual } 5 \\
\text { hemizygous } \\
\text { NROB1 } \\
\text { c.16C>A } \\
\text { p.His6Asn } \\
\text { rs191365011 }\end{array}$ & $\begin{array}{l}\text { Benign } \\
0.026 \\
\text { Sensitivity } 095 \\
\text { Specificity } 0.81\end{array}$ & $\begin{array}{l}\text { Damaging } \\
-3.91\end{array}$ & Poly-morphism & $1.14 \mathrm{e}-3$ \\
\hline
\end{tabular}

Note: LRP2 (NM_004525.2, P98164), LMBR1L (NM_018113.3, Q6UX01), ZFPM2 (NM_012082.3), HSD17B3 (NM_000197.2), INSL3

(NM_001265587.2), NROB1 (NM_000475.5). According to Vihinen (2013, https://onlinelibrary.wiley.com/doi/full/10.1002/humu.22253), we are giving the versions, parameters, and full output of web-based resources: PolyPhen-2: Version v2.2.2r406. parameters cannot be changed. fathmm: Version v2.3. Inherited disease algorithm; weighted; phenotypic association: none. MutationTaster2: parameters cannot be changed.

andividual 1 harbors two LRP2 variants* that we consider non-pathogenic, because of their high population frequency. 
(a)

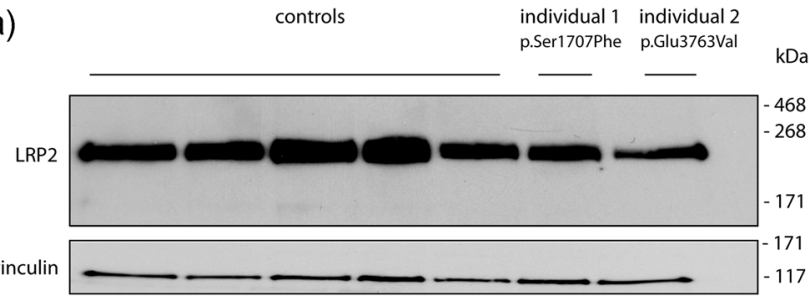

(b)

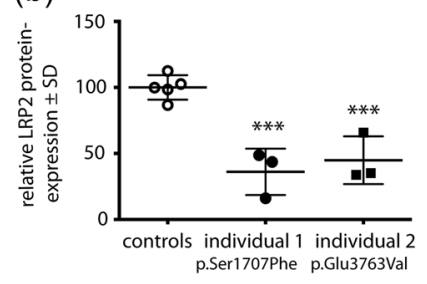

FIGURE 2 Reduced LRP2 protein expression in cell lines carrying heterozygous $L R P 2$ variants. (a) Genital fibroblasts taken from individuals 1 and 2 were analyzed by western blot for LRP2 protein expression in comparison with five control cell lines. Forty micrograms of membrane protein was used for western blot analysis. Vinculin was used as a loading control and for normalization. One representative result of three blots is shown. (b) Quantification of western blots. LRP2 protein expression showed a significant average reduction of $65 \%$ in cells from individual 1 and a significant average reduction of $55 \%$ in cells from individual 2 . Cell cultures and western blots were performed three times. For each control cell line results from three experiments were averaged and plotted as one data symbol. For each mutant, one data symbol represents one experiment. Student's $t$ test, two-tailed, unpaired ${ }^{* * *} p<0.001$. SD: Standard deviation. LRP2 (NM_004525.2) variants in individual 1 (c.5120C>T, p.Ser1707Phe, SCV0019345574) and in individual 2 (c.11288A>T, p.Glu3763Val, SCV0019345577)

to enrich for cases with impaired cellular androgen uptake. Because the concept was novel, we designed a selection scheme with wide biochemical parameters. We identified four unrelated individuals with mutations in genes not previously associated with DSD. Both encode endocytic receptors ( $L R P 2, L M B R 1 L)$. These four individuals did not carry mutations in any of the 100 genes previously associated with DSD (see methods). In a fifth individual, we detected a heterozygous LMBR1L mutation and additional mutations in four DSDassociated genes.

GF of the individuals or transfected cell models, respectively, showed reduced expression of the affected endocytic receptors. That cellular uptake of sex steroids may require carrier proteins in specific cell types was demonstrated in Lrp2-deficient mice, where the hormones are taken up by the endocytic receptor in complex with SHBG (Hammes et al., 2005). We showed that endocytosis of SHBG conjugated to a fluorescent dye is reduced in GF from individuals with mutations in LRP2. With hypospadias, bifid scrotum, and micropenis the phenotype descriptions for our individuals with LRP2 mutations are alike. The non-descended testes in both individuals are strikingly identical to the same phenotype in Lrp2-deficient mice (Hammes et al., 2005). Before testicular descend, the testes are held in the lower abdomen between the cranial suspensory ligament (CSL) and the gubernaculum. Upon testosterone-dependent regression of the (a) control
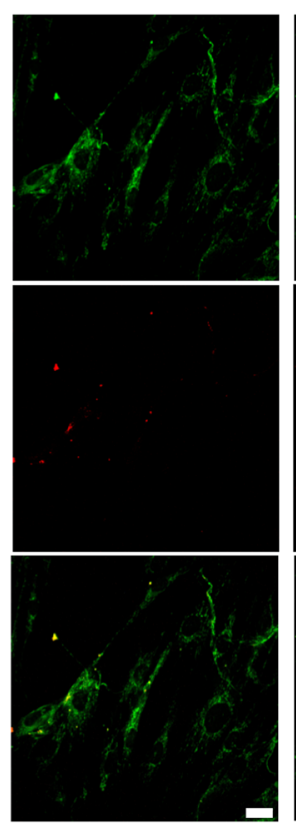

(b)

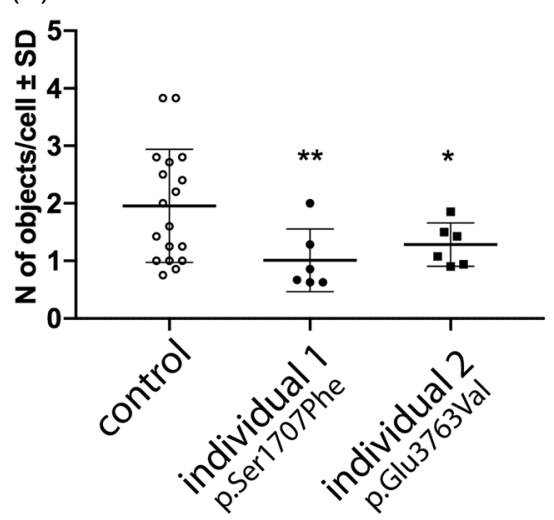

individual 2

individual
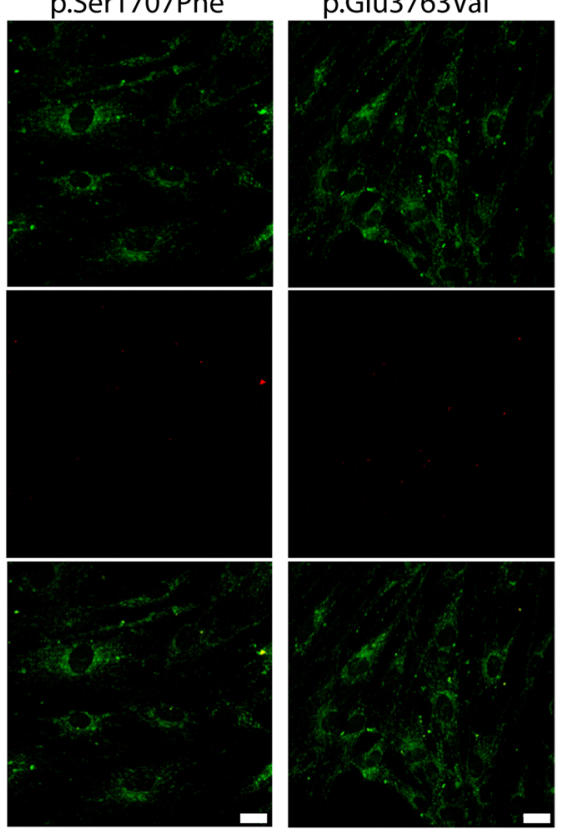

.




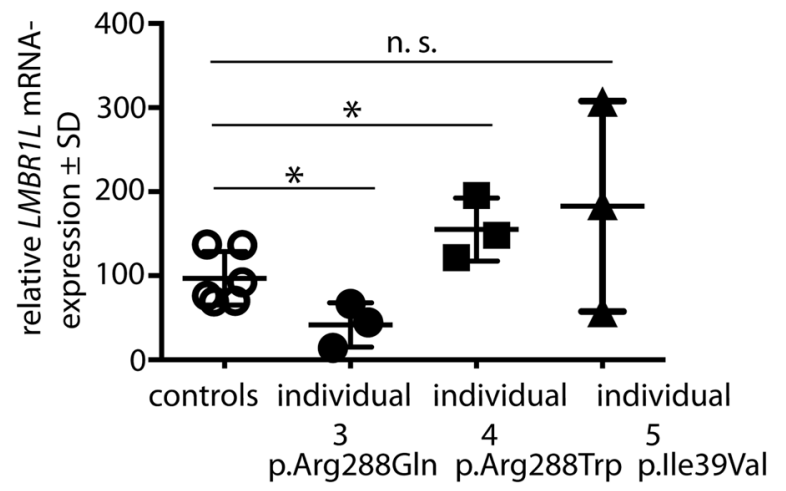

FIGURE 4 LMBR1L mRNA expression in LMBR1L mutant and control GF. Genital skin fibroblasts from cases 3-5 were analyzed by qRT-PCR for LMBR1L mRNA expression in comparison with six control cell lines. GF from individual 3 show a significant reduction of LMBR1L mRNA. GF from individual 4 show a significant upregulation of LMBR1L mRNA. GF from individual 5 show increased $L M B R 1 L$ mRNA levels that are not significant due to large variation. qRT-PCR was performed three times with material taken from three independent cell cultures. Every sample was measured in technical triplicates. Each data symbol represents one experiment (cell culture/ qRT-PCR). 18S rRNA was used for normalization. Student's $t$ test, two-tailed, unpaired ${ }^{*} p<0.05$. SD: Standard deviation. Heterozygous LMBR1L (NM_004525.2) variants in individual 3 (c.863G >A (p.Arg288Gln, SCV0019345578), in individual 4 (c.862C>T (p.Arg288Trp, SCV0019345579), and in individual 5 (c.115A>G (p.lle39Val, SCV0019345580). GF, genital fibroblasts; mRNA, messenger RNA; qRT-PCR, quantitative reverse-transcription polymerase chain reaction

the head. Complete deficiency or certain missense mutations in LRP2 lead to Donnai-Barrow syndrome (Kantarci et al., 2007), a syndrome with a wide phenotypic spectrum which, in mice, depends on modifier genes and gene dose (Xavier et al., 2016). Remarkably, one of the individuals we describe here, was diagnosed with an absence of the septum pellucidum. Whether the other individual with LRP2 mutation lacks the septum pellucidum, too, was not investigated. This finding can be interpreted as a mild midline defect and is consistent with impaired LRP2 function in individual 1.

With three mutations identified in the lipocalin receptor $L M B R 1 L$, we most probably have identified a completely new gene involved in steroid uptake and sex differentiation. Two of the LMBR1L mutations are affecting the same amino acid, p.Arg288. It is appealing to suspect these as possible causes of a steroid uptake deficiency because in haploidy, both mutations reduce the cell surface expression of LMBR1L in a transfected cell model by $65 \%-75 \%$. A dominant effect on cell surface expression of wild-type LMBR1L may be envisioned based on the finding of oligomerization of LMBR1L (Hesselink \& Findlay, 2013). Even though the third mutant, p.lle39Val, shows significantly reduced expression in our transfected cell model, its pathogenicity is uncertain, since individual 5 harbors additional mutations in HSD17B3, ZFPM2, INSL3, and NROB1. The combination of several mutations in DSD genes may be the reason why individual 5 was raised as a girl and was clinically diagnosed only at age 17 with a severe partial androgen insensitivity. LMBR1L is a member of the lipocalin receptor family (Fluckinger et al., 2008; Wojnar et al., 2001). Their ligands, lipocalins, are proteins binding hydrophobic molecules, including steroids. Remarkably, $A P O D$, the androgen inducible gene used for the $A P O D$ assay, is a member of the lipocalin family (Flower, 1996) and might as well mediate cellular steroid uptake in parallel to SHBG. For LMBR1L an endocytic uptake mechanism has been described previously (Fluckinger et al., 2008). LMBR1L and the RBP receptor STRA6 share $17 \%$ identity and $28 \%$ similarity according to EMBOSS needle alignment (Needleman \& Wunsch, 1970). Thus, by similarity, one could envision an uptake mechanism as proposed for retinol via the RBP receptor STRA6 (Kawaguchi et al., 2007), because PSIPRED predicts five of its nine transmembrane helices as porelining helices (Jones, 1999). Based on the molecular structure of STRA6, it is assumed that the hydrophobic ligand retinol passes from RBP into a hydrophobic cavity which allows access to an acceptor on the cytoplasmic side of the membrane (Chen et al., 2016). LMBR1L tissue expression is described to be especially high in testis, pituitary, and adrenal gland (Wojnar et al., 2001) thus consistent with a possible involvement in hormone metabolism. Interestingly, LMBR1L has been found to interact with the melanoma antigen gene protein MAGE-11 (MAGEA11) (Yang et al., 2016). MAGE-11 is known to bind, colocalize, and co-immunoprecipitate with AR through interaction with the $\mathrm{N}$-terminus of $\mathrm{AR}$ in the unliganded conformation within the cytoplasm (Bai et al., 2005). Its expression is high in testis, prostate, placenta, and adrenals.

If we assume the necessity of protein-mediated steroid hormone uptake and consider the role of LRP2 confined to very specific cell types (as in the CSL), we deem it possible that several uptake mechanisms co-exist, expressed in partially overlapping patterns. Again, while STRA6 takes up retinol from RBP in retinal pigment epithelium, LRP2 takes up RBP/retinol in the kidney (Raila et al., 2005). Deficiency of one such transporter may thus fully affect only such cell type or organ that fails to express other transporters at a critical time. Species differences, for example, between mice and humans, may further complicate the situation. For example, in mice, Lmbr1ldeficiency has recently been shown to modulate the Wnt/ $\beta$-catenin pathway specifically in T-lymphocytes (Choi et al., 2019). A reproductive phenotype or intestinal carcinogenesis, as expected, has not been reported. Hence, LMBR1L function clearly depends on cellular background.

An alternative pathway for steroid uptake might be its circulation as conjugate, for example, steroid sulfate, membrane transport, and intracellular deconjugation. Several steroid hormones are present in the circulation as sulfate conjugates (Mueller et al., 2015). A transmembrane carrier protein, SOAT/SLC10A6, is capable of mediating sulfated steroid uptake (Grosser et al., 2013). However, gene targeting of Soat in mice did not reveal any hormonal deficiencies (Bakhaus et al., 2018).

The field of cellular steroid hormone uptake thus remains a difficult one. Final proof for a steroid hormone transporter in human analogous to the thyroid hormone transporter MCT8/SLC16A2 is still missing. The identification of the ecdysone importer Oatp74D in Drosophila, on the one hand, makes it likely that such transporters 
(a)

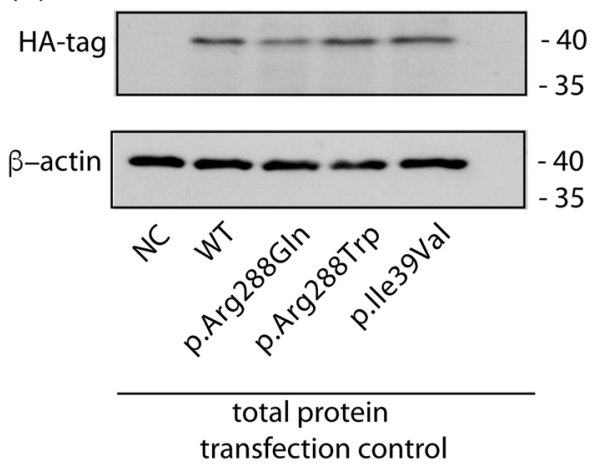

$\mathrm{kDa}(\mathrm{b})$

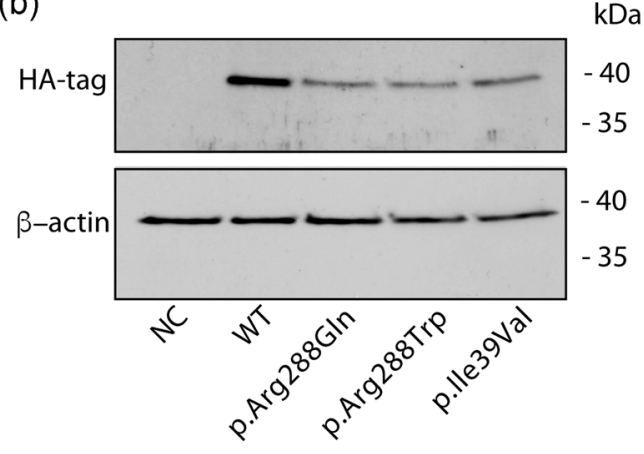

(c)

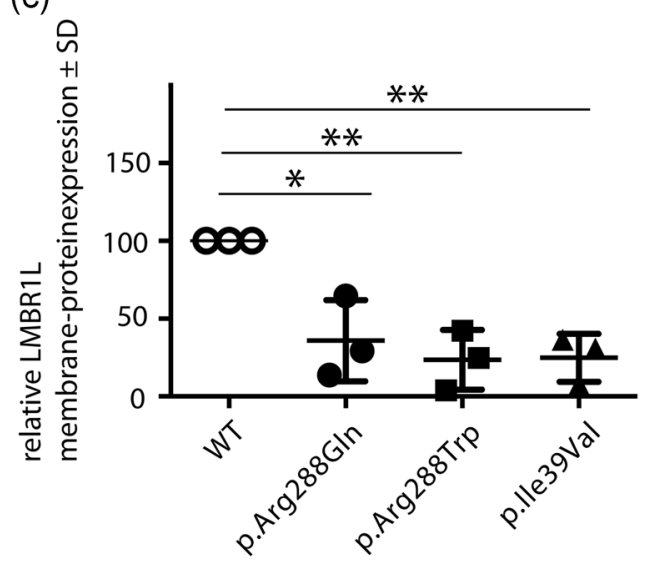

FIGURE 5 Reduced LMBR1L cell surface expression in transfected cells expressing mutant LMBR1L. HAP1-LMBR1L knockout cells were transiently transfected with expression vectors encoding $L M B R 1 L$ wildtype (WT) as well as LMBR1L variants as identified in cases 3-5. (a) Cellular HA-LMBR1L expression: Total cellular protein $(15 \mu \mathrm{l})$ was analyzed by western blot to ascertain transfection and similar expression. An antibody against HA-tag was used to identify LMBR1L. $\beta$-actin was used as loading control. (b) Surface expression of HA-LMBR1L: Protein was biotinylated with a cell-impermeant reagent. Plasma membrane protein fraction was analyzed for LMBR1L expression by western blot directed against the HA-tag. $\beta$-actin was used as loading control. (c) Quantification of cell surface expression levels of LMBR1L mutants compared to WT (set at 100\%). Mean cell surface expression of LMBR1L variants show significant reduction compared to WT. Surface biotinylation was performed three times with material taken from three independent transfections. Each result is plotted as one symbol as percent of the respective WT. (A, B) show representative experiments. Negative control (NC): transfection with empty vector. Student's $t$ test, two-tailed, unpaired ${ }^{*} p<0.05,{ }^{* *} p<0.01$. SD, standard deviation

exist in humans, too, but, on the other hand, their identification failed so far. We did not find mutations in solute carrier superfamily genes in the GF that we subjected to exome sequencing. Is this because the concept is flawed? Or are there so many transporters with overlapping specificities and expression patterns that none of the transporters is essential in humans or mammalian model systems? Or is there, on the contrary, only a very limited set of transporters that transports a very specific ligand which is essential to successfully complete embryonic development and thus individuals with such mutations will never be born?

\section{5 | CONCLUSIONS}

With our approach to select GF for exome sequencing from individuals with incomplete virilization based on biochemical readouts, we identified heterozygous mutations in two endocytic receptor genes, LRP2 and LMBR1L, that reduce their cell membrane expression. In the case of $L R P 2$, this is the first report substantiating in human the results from mice deficient in $L r p 2$. As for LMBR1L, the finding of a second endocytic receptor gene mutated in 46,XY DSD individuals potentially expands the concept of protein-facilitated sex steroid uptake in humans. Diminished intracellular hormone concentrations resulting from disturbed hormone uptake might underlie reduced androgen-mediated gene expression, ultimately presenting as incomplete virilization in individuals with a 46,XY karyotype.

\section{ACKNOWLEDGMENTS}

The authors wish to express their sincere gratitude to Uschi Reuter, Institute of Biochemistry and Molecular Biology Bonn, for invaluable technical and methodological assistance. The use of the confocal microscope at the Imaging Core Facility of the Universitätsklinikum Bonn is gratefully acknowledged. This study was supported by funding from Deutsche Forschungsgemeinschaft DFG (SCHW168/ 
13-1 and HO6028/2-1) and Medical Faculty at Rheinische FriedrichWilhelms-Universität Bonn (BONFOR O-161.0043). HLM expresses her sincere gratitude to the Studienstiftung des deutschen Volkes for continuous support. Open Access funding enabled and organized by Projekt DEAL.

\section{CONFLICT OF INTERESTS}

The authors declare that there are no conflict of interests.

\section{DATA AVAILABILITY STATEMENT}

The variants in LRP2 and LMBR1L reported here have been submitted to ClinVar (https://www.ncbi.nlm.nih.gov/clinvar/; SUB10426257). Individual SCV numbers are given in Table 2.

The data that support the findings of this study are available on request from the corresponding author. The data are not publicly available due to privacy or ethical restrictions.

\section{WEB RESOURCES}

Single nucleotide variants suspected to be DSD causing were analyzed with three tools protein pathogenicity predictors: PolyPhen-2 (http://genetics.bwh.harvard.edu/pph2/) (Adzhubei et al., 2010), MutationTaster2 (http://www.mutationtaster.org) (Schwarz et al., 2014), fathmm v.2.3 (http://fathmm.biocompute.org.uk) (Shihab et al., 2013). Results of the predictions are given in Table 3. Pairwise alignment was performed at https://www.ebi.ac.uk/Tools/psa/ emboss_needle (Needleman \& Wunsch, 1970). Topology prediction was performed with PSIPRED (http://bioinf.cs.ucl.ac.uk/psipred/) (Jones, 1999). Population allele frequencies were taken from gnomAD database (http://gnomad.broadinstitute.org).

\section{ORCID}

Ulrich Schweizer (D) http://orcid.org/0000-0003-1380-4780

\section{REFERENCES}

Adzhubei, I. A., Schmidt, S., Peshkin, L., Ramensky, V. E., Gerasimova, A. Bork, P., \& Kondrashov, A. S. (2010). A method and server for predicting damaging missense mutations. Nature Methods, 7(4), 248-249. https://doi.org/10.1038/nmeth0410-248

Audi, L., Camats, N., Fernandez-Cancio, M., \& Granada, M. L. (2018). Development of laboratory investigations in disorders of sex development. Sexual Development, 12(1-3), 7-18. https://doi.org/ 10.1159/000479719

Baetens, D., Verdin, H., De Baere, E., \& Cools, M. (2019). Update on the genetics of differeneces of sex development (DSD). Best Practice \& Research Clinical Endocrinology \& Metabolism, 33(3), 101271. https:// doi.org/10.1016/j.beem.2019.04.005

Bai, S., He, B., \& Wilson, E. M. (2005). Melanoma antigen gene protein MAGE-11 regulates androgen receptor function by modulating the interdomain interaction. Molecular and Cellular Biology, 25(4), 1238-1257. https://doi.org/10.1128/MCB.25.4.12381257.2005

Bakhaus, K., Bennien, J., Fietz, D., Sánchez-Guijo, A., Hartmann, M., Serafini, R., Love, C. C., Wudy S. A., Bergmann M., \& Geyer J. (2018). Sodium-dependent organic anion transporter (SIc10a6(-/-)) knockout mice show normal spermatogenesis and reproduction, but elevated serum levels for cholesterol sulfate. The Journal of
Steroid Biochemistry and Molecular Biology, 179, 45-54. https://doi. org/10.1016/j.jsbmb.2017.07.019

Brinkmann, A. O., Kuiper, G. G., Ris-Stalpers, C., van Rooij, H. C., Romalo, G., Trifiro, M., Mulder, E., Schweikert H.U., \& Trapman J. (1991). Androgen receptor abnormalities. The Journal of Steroid Biochemistry and Molecular Biology, 40(1-3), 349-352.

Buonocore, F., Clifford-Mobley, O., King, T. F. J., Striglioni, N., Man, E., Sunthatalingham, J. P., Del Valle, I., Lin, L., Lagos, C. F., Rumsby, G., Conway, G. S., \& Achermann (2019) Next-generation sequencing reveals novel genetic variants (SRY, DMRT1, NR5A1, DHH, DHX37) in adults with 46,XY DSD. Journal of the Endocrine Society 3(12), 2341-2360. https://doi.org/10.1210/js.2019-00306

Chen, Y., Clarke, O. B., Kim, J., Stowe, S., Kim, Y. K., Assur, Z., Cavalier, M., von Alpen, D.C., Manzini, C., Blaner, W. S., Frank, J., Quadro, L., Weber, D. J., Shapiro, L., Hendrickson, W. A., \& Mancia, F. (2016). Structure of the STRA6 receptor for retinol uptake. Science, 353(6302), aad8266. https://doi.org/10.1126/ science.aad8266

Choi, J. H., Zhong, X., McAlpine, W., Liao, T. C., Zhang, D., Fang, B., Russell, J., Nair-Gill, E., Zhang, Z., Wang, K. W., Misawa, T., Zhan, X., Choi, M., Wang, T., Li, X., Tang, M., Sun, Q., Yu, L., Murray, A. R., ... Beutler, B. (2019). LMBR1L regulates lymphopoiesis through Wnt/ beta-catenin signaling. Science, 364(6440), eaau0812. https://doi. org/10.1126/science.aau0812

Dumitrescu, A. M., Liao, X. H., Best, T. B., Brockmann, K., \& Refetoff, S. (2004). A novel syndrome combining thyroid and neurological abnormalities is associated with mutations in a monocarboxylate transporter gene. American Journal of Human Genetics, 74(1), 168-175.

Eggers, S., Sadedin, S., den van Bergen, J. A., Robevska, G., Ohnesorg, T., Hewitt, J., Lambeth, L., Bouty, A., Knarston, I. M., Tan, T. Y., Cameron, F., Werther, G., Hutson, J., O'Connell, M., Grover, S. R., Heloury, Y., Zacharin, M., Bergman, P., Kimber, C., ... Sinclair, A. H. (2016). Disorder of sex development: Insights from targeted gene sequencing of a large international patient cohort. Genome Biology, 17, 243. https://doi.org/10.1186/s13059-016-1105-y

Fan, Y., Zhang, X., Wang, R., Huang, Z., Sun, Y., Yao, R., Hunag, X., Ye, J., Han, L., Qiu, W., Zhang, H., Liang, L., Gu, X., \& Yu, Y. (2017). Diagnostic application of targeted next-generation sequencing of 80 genes associated with disorders of sexual development. Science Reports, 7, 44536. https://doi.org/10.1038/ srep44536

Flower, D. R. (1996). The lipocalin protein family: Structure and function. Biochemical Journal, 318(Pt 1), 1-14. https://doi.org/10.1042/ bj3180001

Fluckinger, M., Merschak, P., Hermann, M., Haertle, T., \& Redl, B. (2008). Lipocalin-interacting-membrane-receptor (LIMR) mediates cellular internalization of beta-lactoglobulin. Biochimica et Biophysica Acta/ General Subjects, 1778(1), 342-347. https://doi.org/10.1016/j. bbamem.2007.10.010

Friesema, E. C., Grueters, A., Biebermann, H., Krude, H., von Moers, A., Reeser, M., Barrett, T. G., Svensson J., Kester M. H., Kuiper G. G., Balkassmi S., Uitterlinden A. G., Koehrle J., Rodien P., Halestrap A. P., \& Visser T. J. (2004). Association between mutations in a thyroid hormone transporter and severe X-linked psychomotor retardation. Lancet, 364(9443), 1435-1437.

Grosser, G., Fietz, D., Günther, S., Bakhaus, K., Schweigmann, H., Ugele, B., Brehm, R., Bergmann M., \& Geyer J. (2013). Cloning and functional characterization of the mouse sodium-dependent organic anion transporter Soat (Slc10a6). The Journal of Steroid Biochemistry and Molecular Biology, 138, 90-99. https://doi.org/10.1016/j.jsbmb. 2013.03.009

Hammes, A., Andreassen, T. K., Spoelgen, R., Raila, J., Hubner, N., Schulz, H., Metzger, J., Luppa P. B., Nykjaer A., \& Willnow T. E. 
(2005). Role of endocytosis in cellular uptake of sex steroids. Cell, 122(5), 751-762.

Hesselink, R. W., \& Findlay, J. B. (2013). Expression, characterization and ligand specificity of lipocalin-1 interacting membrane receptor (LIMR). Molecular and Membrane Biology, 30(5-6), 327-337. https:// doi.org/10.3109/09687688.2013.823018

Hornig, N. C., Ukat, M., Schweikert, H. U., Hiort, O., Werner, R., Drop, S. L., Cools, M., Audi L., Ahmed S. F., Demiri J., Rodens P., Worch L., Wehner G., Kulle A. E., Dunstheimer D., Müller-Roßberg E., Reinehr T., Hadidi A. T., Eckstein A. K., ... Holterhus P. M. (2016). Identification of an AR mutation-negative class of androgen insensitivity by determining endogenous AR activity. Journal of Clinical Endocrinology and Metabolism, 101(11), 4468-4477. https:// doi.org/10.1210/jc.2016-1990

Hughes, L. A., McKay-Bounford, K., Webb, E. A., Dasani, P., Clokie, S., Chandaran, H., McCarthy, L., Mohamed, Z., Kirk, J. M. W., Krone, N. P., Allen, S., \& Cole, T. R. P. (2019). Next generation sequencing (NGS) to improve the diagnosis and management of patients with disorders of sex development (DSD). Endocrine Connections, 8(2), 100-110. https://doi.org/10.1530/EC-18-0376

Jones, D. T. (1999). Protein secondary structure prediction based on position-specific scoring matrices. Journal of Molecular Biology, 292(2), 195-202. https://doi.org/10.1006/jmbi.1999.3091

Kantarci, S., Al Gazali, L., Hill, R. S., Donnai, D., Black, G. C. M., Bieth, E., Chassaing, N., Devriendt K., Teebi A., Loscertales M., Robson C., Liu T., MacLaughlin D. T., Noonan K. M., Russell M. K., Walsh C. A., Donahoe P. K., \& Pober B. R. (2007). Mutations in LRP2, which encodes the multiligand receptor megalin, cause Donnai-Barrow and facio-oculo-acoustico-renal syndromes. Nature Genetics, 39(8), 957-959.

Kawaguchi, R., Yu, J., Honda, J., Hu, J., Whitelegge, J., Ping, P., Wiita, P., \& Sun $H$. (2007). A membrane receptor for retinol binding protein mediates cellular uptake of vitamin A. Science, 315(5813), 820-825 https://doi.org/10.1126/science.1136244

Lackner, C., Daufeldt, S., Wildt, L., \& Allera, A. (1998). Glucocorticoidrecognizing and -effector sites in rat liver plasma membrane. Kinetics of corticosterone uptake by isolated membrane vesicles. III. Specificity and stereospecificity. The Journal of Steroid Biochemistry and Molecular Biology, 64(1-2), 69-82.

Mueller, J. W., Gilligan, L. C., Idkowiak, J., Arlt, W., \& Foster, P. A. (2015). The regulation of steroid action by sulfation and desulfation. Endocrine Reviews, 36(5), 526-563. https://doi.org/10.1210/er. 2015-1036

Needleman, S. B., \& Wunsch, C. D. (1970). A general method applicable to the search for similarities in the amino acid sequence of two proteins. Journal of Molecular Biology, 48(3), 443-453. https://doi. org/10.1016/0022-2836(70)90057-4

Okamoto, N., Viswanatha, R., Bittar, R., Li, Z., Haga-Yamanaka, S., Perrimon, N., \& Yamanaka, N. (2018). A membrane transporter is required for steroid hormone uptake in Drosophila. Developmental Cell, 47(3), 294-305. https://doi.org/10.1016/j.devcel.2018.09.012

Okamoto, N., \& Yamanaka, N. (2020). Steroid hormone entry into the brain requires a membrane transporter in Drosophila. Current Biology, 30(2), 359-366. https://doi.org/10.1016/j.cub.2019.11.085

Raila, J., Willnow, T. E., \& Schweigert, F. J. (2005). Megalin-mediated reuptake of retinol in the kidneys of mice is essential for vitamin $A$ homeostasis. Journal of Nutrition, 135(11), 2512-2516. https://doi. org/10.1093/jn/135.11.2512

Rao, G. S. (1981). Mode of entry of steroid and thyroid hormones into cells. Molecular and Cellular Endocrinology, 21(2), 97-108.

Rao, M. L., Rao, G. S., Holler, M., Breuer, H., Schattenberg, P. J., \& Stein, W. D. (1976). Uptake of cortisol by isolated rat liver cells. A phenomenon indicative of carrier-mediation and simple diffusion. Hoppe-Seyler's Zeitschrift Fur Physiologische Chemie, 357(4), 573-584.
Schwartz, C. E., May, M. M., Carpenter, N. J., Rogers, R. C., Martin, J., Bialer, M. G., Ward, J., Marsa S., Lewis J. A., Echeverri R., Lubs H. A., Voeller K., Simensen R. J., \& Stevenson R. E. (2005). Allan-Herndon-Dudley syndrome and the monocarboxylate transporter 8 (МСТ8) gene. American Journal of Human Genetics, 77(1), 41-53.

Schwarz, J. M., Cooper, D. N., Schuelke, M., \& Seelow, D. (2014). MutationTaster2: Mutation prediction for the deep-sequencing age. Nature Methods, 11(4), 361-362. https://doi.org/10.1038/ nmeth.2890

Shihab, H. A., Gough, J., Cooper, D. N., Stenson, P. D., Barker, G. L., Edwards, K. J., \& Day, I. N. (2013). Predicting the functional, molecular, and phenotypic consequences of amino acid substitutions using hidden Markov models. Human Mutation, 34(1), 57-65. https:// doi.org/10.1002/humu.22225

Sinnecker, G. H., Hiort, O., Dibbelt, L., Albers, N., Dörr, H. G., Hauss, H., Heinrich, U., Hemminghaus, M., Hoepffner, W. Holder, M., Schnabel, D., \& Kruse, K. (1996). Phenotypic classification of male pseudohermaphroditism due to steroid 5 alpha-reductase 2 deficiency. American Journal of Medical Genetics, 63(1), 223-230.

Spoelgen, R., Hammes, A., Anzenberger, U., Zechner, D., Andersen, O. M., Jerchow, B., \& Willnow, T. E. (2005). LRP2/megalin is required for patterning of the ventral telencephalon. Development, 132(2), 405-414.

Vihinen, M. (2013). Guidelines for reporting and using prediction tools for genetic variation analysis. Human Mutation, 34(2), 275-277. https:// doi.org/10.1002/humu.22253

Weidemann, W., Linck, B., Haupt, H., Mentrup, B., Romalo, G., Stockklauser, K., Brinkmann, A. O., Schweikert, H. U., \& Spindler, K. D. (1996). Clinical and biochemical investigations and molecular analysis of subjects with mutations in the androgen receptor gene. Clinical Endocrinology, 45(6), 733-739. https://doi. org/10.1046/j.1365-2265.1996.8600869.x

Weidemann, W., Linck, B., Haupt, H., Mentrup, B., Romalo, G, Stockklauser, K, Brinkmann, A. O., Schweikert, H. U., \& Spindler, K. D. (1996). Clinical and biochemical investigations and molecular analysis of subjects with mutations in the androgen receptor gene. Clinical Endocrinology, 99(4), 1393-1399. https:// doi.org/10.1046/j.1365-2265.1996.8600869.x

Willnow, T. E., \& Nykjaer, A. (2010). Cellular uptake of steroid carrier proteins-Mechanisms and implications. Molecular and Cellular Endocrinology, 316(1), 93-102.

Wojnar, P., Lechner, M., Merschak, P., \& Redl, B. (2001). Molecular cloning of a novel lipocalin-1 interacting human cell membrane receptor using phage display. Journal of Biological Chemistry, 276(23), 20206-20212. https://doi.org/10.1074/jbc. M101762200

Xavier, G. M., Seppala, M., Barrell, W., Birjandi, A. A., Geoghegan, F., \& Cobourne, M. T. (2016). Hedgehog receptor function during craniofacial development. Developmental Biology, 415(2), 198-215. https://doi.org/10.1016/j.ydbio.2016.02.009

Xu, Y., Wang, Y., Li, N., Yao, R., Li, G., Li, J., Ding, Y., Chen, Y., Huang, X., Chen, Y., Qing, Y., Yu, T., Shen, Y., Wang, X., Shen, Y., \& Wang, J. (2019). New insights from unbiased panel and whole-exome sequencing in a large Chinese cohort with disorders of sexual development. European Journal of Endocrinology, 181, 311-323. https://doi.org/10.1530/EJE-19-0111

Yamanaka, N., Marques, G., \& O'Connor, M. B. (2015). Vesiclemediated steroid hormone secretion in Drosophila melanogaster. Cell, 163(4), 907-919. https://doi.org/10.1016/j.cell.2015. 10.022

Yang, X., Coulombe-Huntington, J., Kang, S., Sheynkman, G. M., Hao, T., Richardson, A., Sun, S., Shen Y. A., Murray R. R., Spirohn K., Begg B. E., Duran-Frigola M., MacWilliams A., Pevzner S. J., 
Zhong Q., Trigg S. A., Tam S., Ghamsari L., Sahni N., ... Vidal M. (2016). Widespread expansion of protein interaction capabilities by alternative splicing. Cell, 164(4), 805-817. https://doi.org/10.1016/j. cell.2016.01.029

\section{SUPPORTING INFORMATION}

Additional supporting information may be found in the online version of the article at the publisher's website.
How to cite this article: Marko, H. L., Hornig, N. C., Betz, R. C., Holterhus, P.-M., Altmüller, J., Thiele, H., Fabiano, M.,

Schweikert, H.-U., Braun, D., \& Schweizer, U. (2022). Genomic variants reducing expression of two endocytic receptors in $46, X Y$ differences of sex development. Human Mutation, 43, 420-433. https://doi.org/10.1002/humu.24325 